VIEIRA, ME; FREITAS, MSM; PEÇANHA, DA; LIMA, TC; MARTINS, MA; VIEIRA, IJC. 2021. Arbuscular mycorrhizal fungi and phosphorus in spilanthol and phenolic compound yield in jambu plants. Horticultura Brasileira 39: 192-198. Doi: http://dx.doi.org/10.1590/s0102-0536-20210210

\title{
Arbuscular mycorrhizal fungi and phosphorus in spilanthol and phenolic compound yield in jambu plants
}

\author{
Marlene E Vieira ${ }^{1} \mathbb{D}$; Marta Simone M Freitas ${ }^{1} \mathbb{D}$; Diego A Peçanha ${ }^{1} \mathbb{D}$; Thaísa C Lima ${ }^{1} \mathbb{D}$; Marco Antonio \\ Martins ${ }^{1} \mathbb{D}$; Ivo José C Vieira ${ }^{1} \mathbb{D}$
}

${ }^{1}$ Universidade Estadual do Norte Fluminense Darcy Ribeiro (UENF), Campos dos Goytacazes-RJ, Brasil; marlenevieira_evan@hotmail. com (correspondence author); martasimonefreitas@hotmail.com; diegopecanha333@yahoo.com.br; thaisacapato@hotmail.com; marco@ uenf.br; curcinovieira@gmail.com

\begin{abstract}
Jambu has spilanthol and phenolic compounds that are responsible for several medicinal properties. Besides improving nutrient absorption, arbuscular mycorrhizal fungi (AMF) can change secondary metabolites' yield. Thus, the aim of the current study was to evaluate AMF inoculation and $\mathrm{P}$ influence on shoot dry biomass yield, macronutrient content $(\mathrm{N}, \mathrm{P}, \mathrm{K}, \mathrm{Ca}$ and $\mathrm{Mg}$ ), total phenol contents and spilanthol percentage in jambu plants. The experiment followed a randomized block design at $3 \times 4$ factorial arrangement, with two AMF (Rhizophagus clarus and Claroideoglomus etunicatum) and without AMF, at four P doses $(0,30,60$ and $90 \mathrm{mg} / \mathrm{kg}$ of soil), with four replicates. Plants inoculated with $R$. clarus and C. etunicatum, grown without phosphate fertilization, presented increase by 23 and 12 times, respectively, in comparison to plants without AMF. The relative spilanthol area in plants inoculated with $R$. clarus, without phosphate fertilization, reached $2.4 \%$. Shoot dry biomass yield of jambu plants and the $\mathrm{P}, \mathrm{K}, \mathrm{Ca}$ and $\mathrm{Mg}$ contents were higher when plants were inoculated with $R$. clarus at the lowest $\mathrm{P}$ doses. The AMF also increased the contents of total phenols in plants fertilized with $60 \mathrm{mg} \mathrm{kg}^{-1}$. This $\mathrm{P}$ dose increased spilanthol concentration in jambu plants inoculated with C. etunicatum.
\end{abstract}

Keywords: Acmella oleacea, Rhizophagus clarus, Claroideoglomus etunicatum, mycorrhizae, secondary metabolism, nutrients.

\section{RESUMO}

Fungos micorrízicos arbusculares e fósforo na produção de espilanthol e composto fenólico em plantas de jambu

O jambu possui espilantol e compostos fenólicos responsáveis por muitas de suas propriedades medicinais. Além de melhorar a absorção de nutrientes, os fungos micorrízicos arbusculares (FMA) podem alterar a produção de metabólitos secundários. Assim, objetivou-se avaliar a influência da inoculação de FMA e doses de P na produção de biomassa seca da parte aérea, conteúdo dos macronutrientes $(\mathrm{N}, \mathrm{P}, \mathrm{K}, \mathrm{Ca}$ e $\mathrm{Mg})$, conteúdo de fenóis totais e concentração de espilantol em plantas de jambu. $\mathrm{O}$ experimento foi conduzido em delineamento blocos ao acaso, em esquema fatorial $3 \times 4$, com dois FMA (Rhizophagus clarus e Claroideoglomus etunicatum) e sem FMA, em quatro doses de P (0, 30, 60 e $90 \mathrm{mg} / \mathrm{kg}$ de solo), com quatro repetições. Plantas inoculadas com R. clarus e C. etunicatum, cultivadas sem adubação fosfatada, apresentaram incremento de 23 e 12 vezes, respectivamente, na biomassa seca da parte aérea, em comparação com plantas sem FMAs. A concentração de espilantol nas plantas inoculadas com $R$. clarus, sem adubação fosfatada foi $2,4 \%$. A produção da biomassa seca da parte aérea das plantas de jambu e também os conteúdos de $\mathrm{P}, \mathrm{K}, \mathrm{Ca}$, e $\mathrm{Mg}$ são maiores quando inoculadas com $R$. clarus nas menores doses de P. Essa espécie de FMA, também aumenta os conteúdos de fenóis totais nas plantas, quando adubadas com $60 \mathrm{mg} \mathrm{kg}^{-1}$. A dose $60 \mathrm{mg} \mathrm{kg}^{-1}$ de P aumenta a concentração de espilantol nas plantas de jambu quando inoculadas com C. etunicatum.

Palavras-chave: Acmella oleácea, Rhizophagus clarus, Claroideoglomus etunicatum, micorriza, metabolismo secundário, nutrientes.

\section{Received on May 18, 2020; accepted on April 21, 2021}

\begin{abstract}
$A_{\mathrm{f}}^{\mathrm{cm}}$ cmella oleacea, from the Asteraceae family, popularly known as 'jambu' and 'agrião do Pará', is an herbaceous plant quite used as spice in some typical dishes in Northern Brazil, such as 'tacacá' or 'pato no tucupi'. It is also used in the popular medicine to treat some illnesses such as sore throat, toothache and anemia (Gusmão \&
\end{abstract}

Gusmão, 2013).

This plant species has gained relevance in scientific research due to its medicinal properties, which are attributed to its different chemical constituents, among them spilanthol (N-alkylamide). Spilanthol performs many biological activities, among them antiarthritic (Escobedo-Martinez et al., 2017), acaricide (Oliveira et al., 2018), anesthetics and anti-wrinkles; therefore, it has gained the attention of pharmaceutical, food and cosmetics industries (Barbosa et al., 2016). It is important to highlight that this plant species also presents alkaloids (Gerbino et al., 2016) and flavonoids (Chakraborty et al., 2010). 
Genetic, physiological and environmental factors have strong influence on the biosynthesis of secondary metabolites in plants and, consequently, on their active ingredients (GobboNeto \& Lopes, 2007). Arbuscular mycorrhizal fungi (AMF) enlarge the root absorption area in host plants through hyphae and improve nutrient absorption, mainly phosphorus (Rocha et al., 2012). Besides contributing to improve plant nutrition, AMFs work as bio-regulators interfering in plant phyto-hormonal balance by influencing plant development and mitigating environmental stress effects. Thus, they act as bio-protectors (Rouphael et al., 2015) that allow biomass increase and change secondary metabolites' production (Bonfim et al., 2015).

Some studies have shown AMF efficiency in maximizing secondary metabolites' production and/or nutrient absorption in many medicinal plants such as Catharanthus roseus (Monnerat et al., 2018), Calendula officinalis (Heitor et al., 2016), Wedilia chinensis (Nisha \& Rajeshkumar, 2010) and Mentha arvensis (Freitas et al., 2006). However, the literature lacks studies about $A$. oleracea, with emphasis on associating AMF with phosphorus fertilization to maximize the synthesis of secondary metabolite compounds accounting for medicinal properties. Therefore, it is worth highlighting the important nature of studies such as the present one. Accordingly, the aim of this study was to assess the AMF inoculation effects on shoot dry biomass production, macronutrients content $(\mathrm{N}, \mathrm{P}, \mathrm{K}, \mathrm{Ca}$ and $\mathrm{Mg}$ ), total phenols and on spilanthol concentration in A. oleaceae plants, at different $\mathrm{P}$ doses.

\section{MATERIAL AND METHODS}

The experiment was carried out in a greenhouse covered with low-density polyethylene film (100 $\mu \mathrm{m})$ and $50 \%$ Sombrite ${ }^{\circledR}$ grill. The greenhouse is located in the Unidade de Suporte à Pesquisa of the Centro de Agricultura, Ciências e Tecnologias in the Universidade Estadual do Norte Fluminense Darcy Ribeiro, UENF, campus $\left(21^{\circ} 45^{\prime} \mathrm{S}, 41^{\circ} 20^{\prime} \mathrm{W}\right.$, altitude 11 $\mathrm{m})$, Campos dos Goytacazes County, Rio de Janeiro State. The minimum and maximum temperatures recorded throughout the experiment were $18^{\circ} \mathrm{C}$ and $31^{\circ} \mathrm{C}$, respectively, on average.

The experiment was conducted in randomized block design with four replicates, at $3 \times 4$ factorial arrangement, where the treatments were three microbiological treatments (a control without AMF, with Rhizophagus clarus and Claroideoglomus etunicatum) and 4 phosphorus doses $(0,30,60,90 \mathrm{mg} /$ $\mathrm{kg}$ of soil), thus totaling 48 plots. The experimental unit was a plastic pot containing $6 \mathrm{~kg}$ of soil and 5 plants.

The soil used to prepare the inoculation with AMF and the substrate was classified as $\mathrm{Tb}$ Dystrophic Yellow Argisol. Soil was sampled at 0 to 20 $\mathrm{cm}$ layer at Antônio Sarlo Agricultural School (Campos dos Goytacazes-RJ, Brazil). Samples were sieved in $2 \mathrm{~mm}$ mesh and mixed with silica sand at 1:1 $(\mathrm{v} / \mathrm{v})$ ratio. Subsequently, samples were sterilized twice in autoclave $121^{\circ} \mathrm{C}$ for 1 $\mathrm{h}$, each time, in order to eliminate native AMFs. Its chemical profiles were: $\mathrm{pH}$ $\left(\mathrm{H}_{2} \mathrm{O}\right)=4.5 ; \mathrm{S}_{-} \mathrm{SO}_{4}=19 \mathrm{mg} \mathrm{dm}^{-1} ; \mathrm{P}=6$ $\mathrm{mg} \mathrm{dm}{ }^{-1} ; \mathrm{K}^{+}=1.7 \mathrm{mmolc} \mathrm{dm}{ }^{-1} ; \mathrm{Ca}^{2+}=$ 9.20 mmolc dm ${ }^{-1} ; \mathrm{Mg}^{2+}=12.1 \mathrm{mmolc}$ $\mathrm{dm}^{-1} ; \mathrm{Al}^{3+}=3.40$ mmolc dm ${ }^{-1} ; \mathrm{H}+\mathrm{Al}=$ $34.8 \mathrm{mmolc} \mathrm{dm}^{-1} ; \mathrm{Na}^{+}=1.40 \mathrm{mmolc} \mathrm{dm}^{-1}$; $\mathrm{C}=490 \mathrm{~g} \mathrm{dm}^{4} ; \mathrm{MO}=8.45 \mathrm{~g} \mathrm{dm}^{-1} ; \mathrm{CTC}=$ $59.2 \mathrm{mmolc} \mathrm{dm}^{-1} ; \mathrm{SB}=24.4 \mathrm{mmolc} \mathrm{dm}^{-1}$; $\mathrm{V}=41 \% ; \mathrm{m}=12 \%$.

Liming was estimated according to the Comissão de Fertilidade do Solo do Estado de Minas Gerais (1999). Soil pH was adjusted using dolomite limestone. Phosphorus doses were applied to the soil 30 days after limestone application, based on Rodrigues et al. (2014). $\mathrm{KH}_{2} \mathrm{PO}_{4}$ and $\mathrm{NaH}_{2} \mathrm{PO}_{4} \cdot \mathrm{H}_{2} \mathrm{O}$ were used as phosphorus sources. Potassium (K) content was corrected by adding $\mathrm{KH}_{2} \mathrm{PO}_{4}$ and $\mathrm{K}_{2} \mathrm{SO}_{4}$ to the soil. Soil samples were incubated for 30 days and $P$ content analysis applied to the soil was conducted after the necessary incubation time, using the Mehlich ${ }^{1}$ extractor. The following values were recorded: 6,19 , 25 and $35 \mathrm{mg} \mathrm{kg}^{-1}$, respectively. These values correspond to the applied $\mathrm{P}$ doses $\left(0,30,60\right.$ and $\left.90 \mathrm{mg} \mathrm{kg}^{-1}\right)$ and soil $\mathrm{pH}$ after correction was 5.9. During the experiment we applied nitrogen in three times $(20 \mathrm{mg} / \mathrm{kg})$ using $\mathrm{NH}_{4} \mathrm{NO}_{3}$. The first application was at 20 days after sowing and the others were performed every 20 days.

Two AMF species (Rhizophagus clarus and Claroideoglomus etunicatum) from the inoculum bank of the Soil Microbiology Department of UENF Laboratory were used in the experiment. The specimens were multiplied in association with maize (Zea mays) for 90 days. Maize seeds were four times immersed in $0.5 \%$ hypochlorite solution for 15 minutes in order to be consecutively sanitized. Ninety (90) days later, shoots were pruned and the pots were covered with paper bags. Samples were treated without irrigation for 30 days to make fungal sporulation easier. Subsequently, the soil mix added with colonized roots and AMF spores was stored in a cold chamber at $4^{\circ} \mathrm{C}$ until the time to perform the experiment.

Jambu seeds were provided by Universidade Federal Rural da Amazonia (Belém-PA, Brazil). Fifteen (15) jambu seeds were sterilized with $0.5 \%$ hypochlorite solution for 15 minutes, and then sown in 6-L pots filled with sterilized and fertilized substrate. The total $120 \mathrm{~cm}^{3}$ of inoculum from each fungal species was applied to the $2 \mathrm{~cm}$ and $3 \mathrm{~cm}$ layers, in the pots, at sowing time. Spores extraction from each AMF species was carried out based on the wet sieving method (Gerdemann \& Nicolson, 1963). The quantity of spores in each inoculum was $1088 / 50 \mathrm{~mL}$ of soil and $3135 / 50 \mathrm{~mL}$ of soil in R. clarus and C. etunicatum, respectively. Treatments that did not receive fungi needed $120 \mathrm{~cm}^{3}$ of sterilized soil for AMF multiplication. Seeds were trimmed 20 days after germination; 5 plants were left in each pot. Plants were irrigated with deionized water throughout the experiment.

Plants were harvested between 07:00 and 09:00 am, 70 days after sowing, at the reproduction phase (Gusmão \& Gusmão, 2013). Shoots and roots were separated from each other. Shoot dry biomass yield, nutrient $(\mathrm{N}, \mathrm{P}, \mathrm{K}, \mathrm{Ca}$, $\mathrm{Mg}$ ) and total phenol concentrations, and the shoots related to spilanthol were determined in the essential oils. 
Shoots were stored in properly identified paper bags in separate, dried in forced air-circulation oven at $40^{\circ} \mathrm{C}$ for 96 hours and shoot dry biomass was determined. Shoot dry biomass was ground in Wiley knife mills and stored in sealed and identified flasks until the time of the analysis.

Samples were chemically featured through open digestion in $\mathrm{HNO}_{3}$ and $\mathrm{H}_{2} \mathrm{O}_{2}$ to find the major and minor elements quantified through inductively coupled plasma spectroscopy (Shimadzu ${ }^{\circledR}$ ICPE-9000). Nitrogen (N) content was determined based on the sulfur digestion method, according to Nessler (Jackson, 1965).

The methodology described by Anderson \& Ingram (1993) was used to determine the total phenols. The following procedures were performed: $0.375 \mathrm{~g}$ of shoot dry biomass extracted with $50 \%$ methanol were weighed and exposed to water bath $\left(80^{\circ} \mathrm{C}\right)$ for 1 hour. The material was filtered and added with $0.2 \mathrm{~mL}$ of the sample, 7.3 $\mathrm{mL}$ of deionized water, $0.5 \mathrm{~mL}$ of Folin-Dennis and $2 \mathrm{~mL}$ of $17 \%$ sodium carbonate. The reading was performed in spectrophotometer Specord $\AA$, at absorbance $760 \mathrm{~mm}, 20$ minutes after the last procedure. Results were expressed in $\mathrm{g} \mathrm{kg}^{-1}$.

Spilanthol concentration was expressed in percentage (mass/mass) and estimated based on essential oils (oil g/100 g of shoot dry biomass). The essential oil was extracted by hydrodistillation, in Clevenger apparatus, with $2 \mathrm{~L}$ flask. Extraction time lasted 90 minutes. Hydrolate was separated from the aqueous phase through liquid-liquid partition in separation funnel and washed in 15 $\mathrm{mL}$ dichloromethane in order to purify the essential oil. Hydrolate and solvent were then collected and stored under exhaust hood at room temperature until they reached total solvent evaporation. Spilanthol identification in essential oils was conducted in Gas Chromatograph coupled to a Mass Spectrometer (GCMS Shimatzu model QP5050A) adjusted to $30 \mathrm{~m}$ long DB-5 capillary column (diameter, $0.25 \mathrm{~mm}$; and $0.25 \mu \mathrm{m}$ thickness,) at $220^{\circ} \mathrm{C}$, inside the injector, and at $240^{\circ} \mathrm{C}$, in the detector, at initial temperature $100^{\circ} \mathrm{C}$ to $280^{\circ} \mathrm{C}$. Substances were identified by comparing the mass aspects to the CG/EM device database.

Roots were washed in running water sieved in different meshes, in each microbiological treatment, in order to determine mycorrhizal colonization and to avoid contamination in AMFs or root losses. Approximately $3 \mathrm{~g}$ of fine roots were separated and stored in $50 \%$ ethanol to determine mycorrhizal colonization based on the methodology described by Grace \& Stribley (1991), adapted to jambu roots: $5 \% \mathrm{KOH}$ at $90^{\circ} \mathrm{C}$ for 10 minutes, alkaline hydrogen peroxide $\left(\mathrm{H}_{2} \mathrm{O}_{2}\right)$ placed in $5 \% \mathrm{HCl}$ for 5 minutes and in $0.05 \%$ trypan blue for 10 minutes, at $90^{\circ} \mathrm{C}$. After staining, 10 root segments were sliced with tweezers. Some drops of glycerol acid were added to the root slices, which were, then, covered with coverslip. Samples were taken to optical microscope to assess the presence of AMF structures based on procedures described by Giovanetti $\&$ Moose (1980).

Mycorrhizal dependency (MD) was determined based on shoot dry biomass, according to the following formula:

$\mathrm{MD}=[(\mathrm{SBM}-\mathrm{SBNM}) / \mathrm{SBM}] \times 100$

Where $\mathrm{MD}=$ mycorrhizal dependency; $\mathrm{SBM}=$ shoot dry biomass yield of mycorrhizal plants; SBNM = shoot dry biomass yield of non-mycorrhizal plants, according to Plenchette et al. (1983) for each of the used P doses $(0$, 30,60 and $90 \mathrm{mg} \mathrm{kg}^{-1}$ ).

The collected experimental data were subjected to analysis of variance, whenever differences were detected through $\mathrm{F}$ test at $5 \%$ probability level. The polynomial regression analysis was applied to shoot dry biomass yield data, percentage of mycorrhizal colonization and macronutrient content $(\mathrm{P}, \mathrm{K}, \mathrm{Ca}$ and $\mathrm{Mg}$ ). Data about nitrogen, total phenols and spilanthol concentration were subjected to Tukey test at 5\% probability level in order to estimate the significance between means. It is important to highlight that variables $\mathrm{N}$ content, total phenols content and spilanthol concentration were not subjected to regression analysis, because the control treatment (without AMFs and without $\mathrm{P}$ dose) was not analyzed due to lack of vegetal material for its performance.

\section{RESULTS AND DISCUSSION}

The effects of interactions between fungal species and P doses on shoot dry biomass and mycorrhizal colonization data are shown on Figures $1 \mathrm{~A}$ and 1B, respectively. There was quadratic regression in inoculated and noninoculated plants, which recorded maximum shoot dry biomass yield (4.8, 4.8 and $4.0 \mathrm{~g} / \mathrm{plant})$ at estimated doses $88.4,61.3$ and $69.1 \mathrm{mg} \mathrm{kg}^{-1}$ in treatments without inoculation, and in the ones inoculated with $R$. clarus and C. etunicatum, respectively. Shoot dry biomass yield of plants inoculated with $R$. clarus ( $1.25 \mathrm{~g} /$ plant) increased 23 times and C. etunicatum ( $0.63 \mathrm{~g} / \mathrm{plant})$ increased 12 times when compared with plants non-inoculated with AMF $(0.05 \mathrm{~g} /$ plant $)$ (Figure 1A). Mycorrhizal colonization was influenced by the $\mathrm{P}$ doses; moreover, phosphate fertilizationfree plants inoculated with $R$. clarus and C. etunicatum colonized $92.5 \%$ and $75 \%$ of the roots, respectively. The percentage of mycorrhizal colonization decreased as the $\mathrm{P}$ doses increased.

Data in the present study showed the efficiency of AMFs to boost plant growth under phosphate fertilization-free. Such AMF benefits are likely related to higher mycorrhizal colonization in plant roots at low phosphorus doses. Accordingly, Moreira \& Siqueira (2006) reported that the small addition of nutrients to soils poor in phosphorus favors colonization and sporulation, although these factors can be inhibited by high doses of these nutrients. AMFs increased the shoot dry biomass yield at the aforementioned doses; this outcome can be related to the well-developed root system of the inoculated plants, a fact that has consequently improved water and nutrient absorption (Augé et al., 2016). Yadav et al. (2012) assessed the influence of two AMF species on the development of micropropagated seedlings and observed that variables plant height, number of branches, leaf area, dry matter mass production and chlorophyll content were higher in 


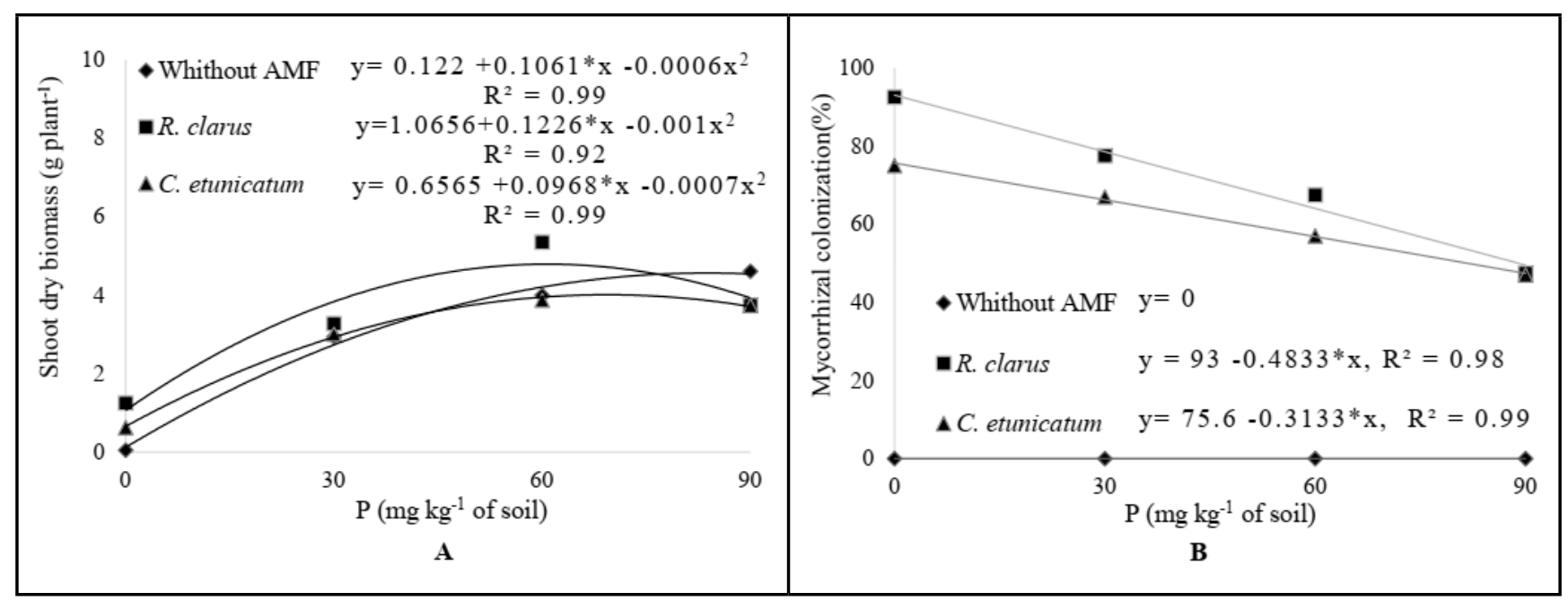

Figure 1. Effect of inoculation AMF and P rates on shoot dry biomass (A) and mycorrhizal colonization (B) in jambu plants (A. oleracea). Campos dos Goytacazes, UENF, 2016.

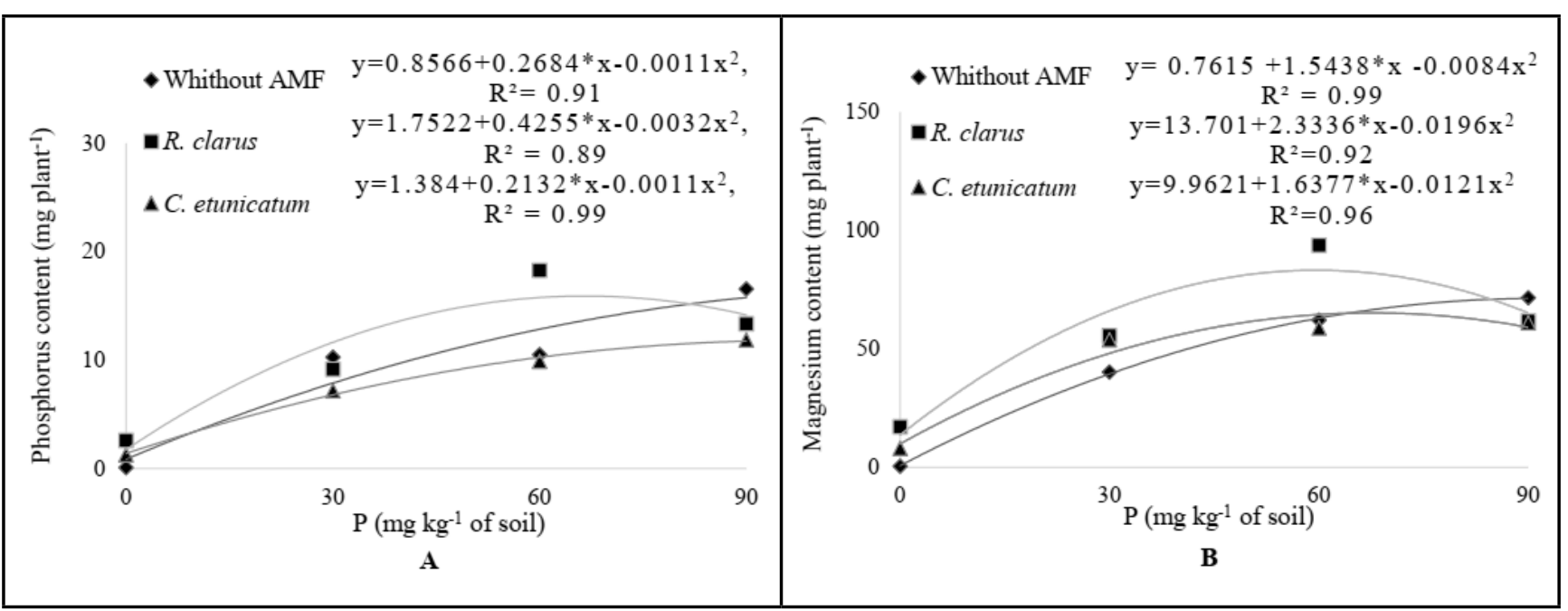

Figure 2. Effect of AMF inoculation and $\mathrm{P}$ doses on phosphorus (A) and magnesium contents (B) in jambu plants (A. oleracea). Campos dos Goytacazes, UENF, 2016.

seedlings inoculated with AMFs than in non-inoculated plants. They reported the growth and survival of seedlings inoculated with AMFs likely due to increased nutrient absorption.

There was significant interaction between AMF species and $\mathrm{P}$ doses in $\mathrm{P}$ and $\mathrm{Mg}$ accumulation in plant shoot (Figure 2A and 2B). The highest contents of $\mathrm{P}$ and $\mathrm{Mg}$ (18.26 and $93.76 \mathrm{mg} /$ plant) were observed in plants inoculated with $R$. clarus at estimated fertilization with phosphate at the order of 66.5 and 59.5 $\mathrm{mg} \mathrm{kg}{ }^{-1}$, respectively. The content of these nutrients in the shoot of plants inoculated with C. etunicatum, without fungi, increased as the $\mathrm{P}$ doses applied to the soil also increased.
Calcium (Ca) and $\mathrm{K}$ contents (Figures 3A and 3B) in all treatments presented quadratic regression. Thus, the highest $\mathrm{Ca}$ content, $77.30 \mathrm{mg} / \mathrm{plant}$, was observed in the treatment with $R$. clarus and $60 \mathrm{mg} / \mathrm{kg}$ of $\mathrm{P}$. This same treatment showed the highest potassium contents ( $146.15 \mathrm{mg} /$ plant). Contents of these nutrients were positively affected by AMF inoculation when plants were not subjected to fertilization with phosphate.

There was no significant difference in $\mathrm{N}$ content in the shoot between treatments concerning inoculation with the two AMF species and lack of phosphate fertilization (Table 1). Control plants (without AMF and without phosphate fertilization) did not develop well; thus, there was not plant material enough to perform the nutrient analysis. However, plants grown with $60 \mathrm{mg} / \mathrm{kg}$ of $\mathrm{P}$ and inoculated with $R$. clarus, recorded $72 \%$ and $45.4 \%$ growth in comparison to plants inoculated with C. etunicatum and to the ones without inoculation, respectively (Table 1 ). Treatments without fungi showed higher $\mathrm{N}$ content when plants were treated with the highest $\mathrm{P}$ doses (Table 1).

Phosphorus is an essential macronutrient for plant metabolism, since it plays important role in respiration processes and photosynthesis, which are part of plant metabolism (Marschner, 2012). Accordingly, based on the 


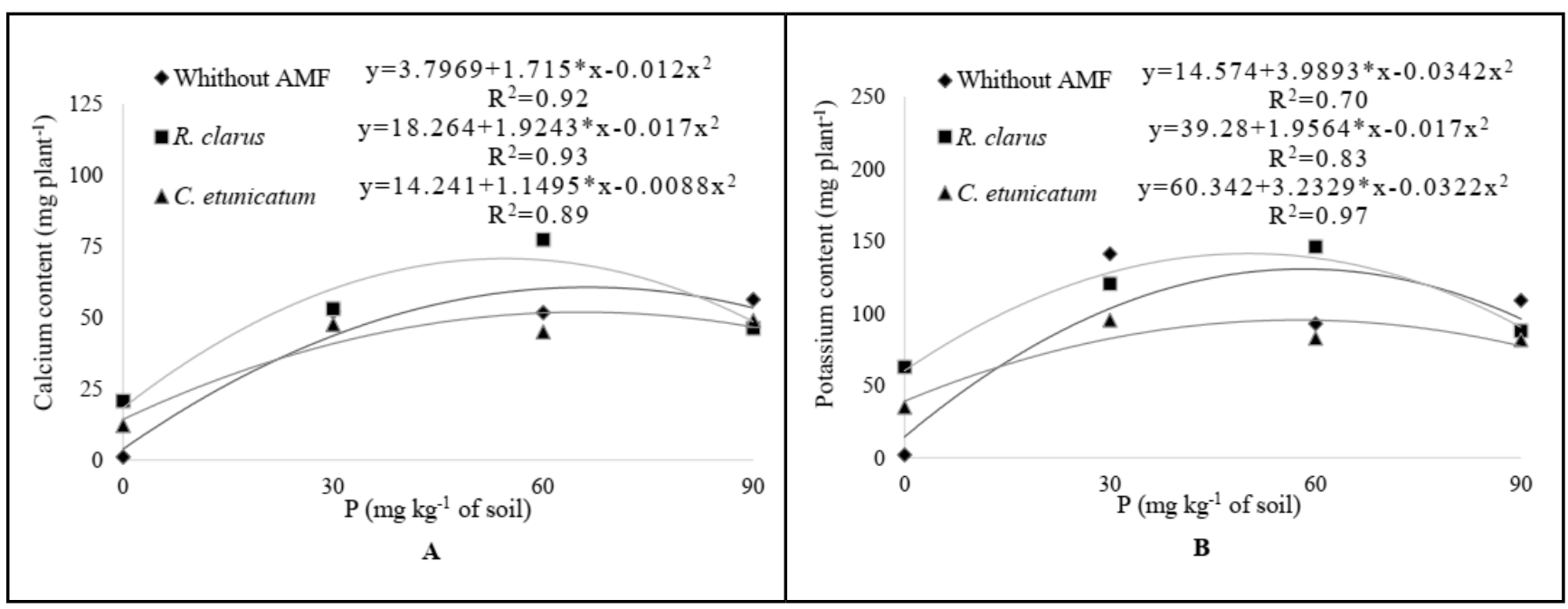

Figure 3. Effect of AMF inoculation and $\mathrm{P}$ doses on calcium $(\mathrm{A})$ and potassium content $(\mathrm{B})$ in jambu plants $($ A. oleracea). Campos dos Goytacazes, UENF, 2016.

present results, macronutrient content increase is likely related to increased $P$ availability, since AMF symbiosis is indicative of two partners and of bidirectional transportation of different nutrients, minerals and carbon through symbiotic interfaces (Wang et al., 2017). Root absorption zone expansion triggers hyphae development in fungi and this process spreads and increases the surface area in contact with the soil. Such a contact favors the absorption of nutrients such as phosphorus and of other macro and micronutrients, as shown by Karagiannidis et al. (2011), who observed increased N, P, Ca, Mg, $\mathrm{B}, \mathrm{Zn}, \mathrm{Fe}$ and $\mathrm{Cu}$ content in Origanum vulgare and Mentha in FMA inoculated plants.

Plants inoculated with $R$. clarus recorded the highest mycorrhizal dependency indices (Figure 4), which reached $95.7 \%$ when plants were grown under phosphate fertilization, as well as $10.3 \%$ and $25.2 \%$, at 30 and $60 \mathrm{mg} \mathrm{kg}^{-1}$ $\mathrm{P}$ doses, respectively. However, jambu

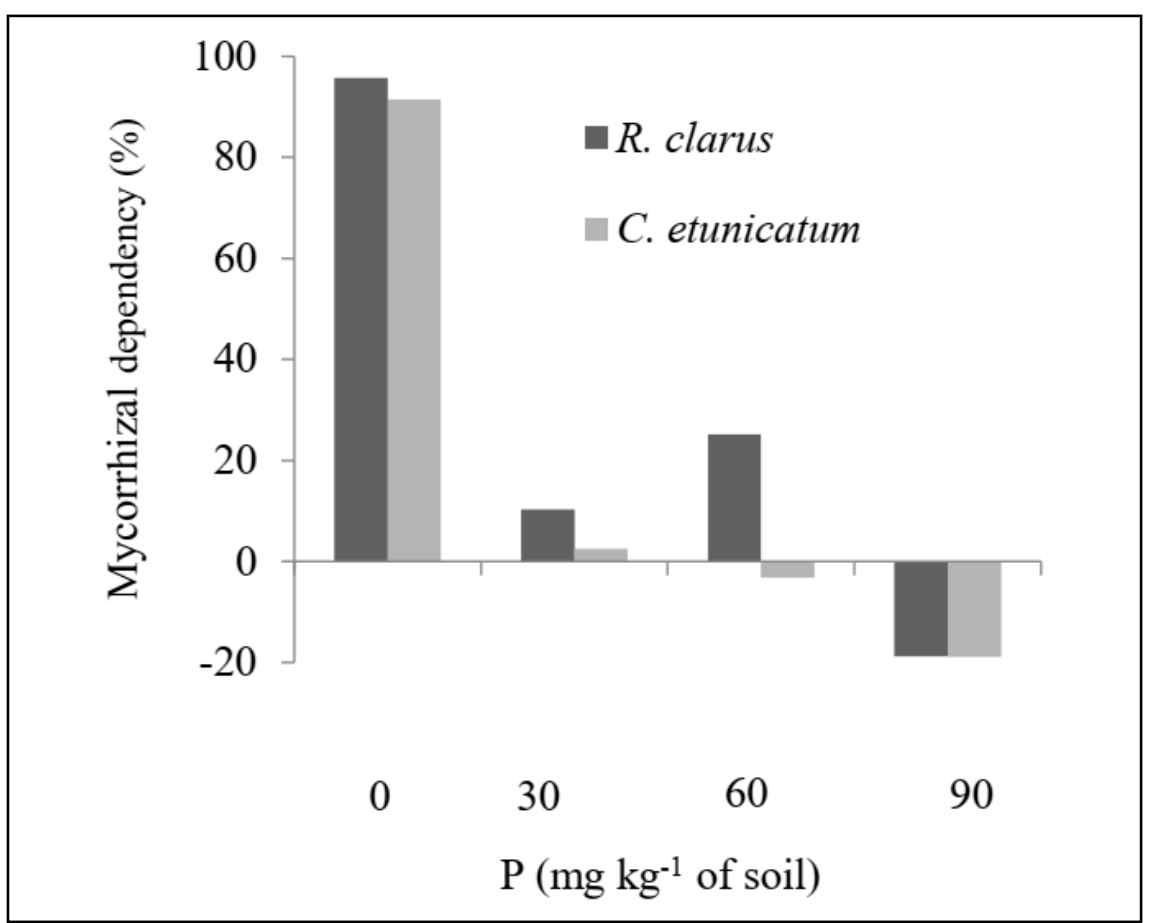

Figure 4. Mycorrhizal dependency on dry matter shoot production of mycorrhizal jambu plants (A. oleracea) at different P doses. Campos dos Goytacazes, UENF, 2016. plants did not present dependence on this AMF species when they were subjected to the highest dose $(90 \mathrm{mg}$ $\mathrm{kg}^{-1}$ ). On the other hand, jambu plants inoculated with $C$. etunicatum, without phosphate fertilization, recorded $91.5 \%$ mycorrhizal dependency (Figure 4), which reached $2.5 \%$ at the dose of 30 $\mathrm{mg} \mathrm{kg}^{-1}$. Jambu plants showed negative dependence on this fungus at the highest $\mathrm{P}$ dose (90 $\mathrm{mg} \mathrm{kg}^{-1}$ ).

The dependency of jambu plants subjected to low P levels in the soil to mycorrhizal fungi is clear in both AMF species. It is important observing that jambu plants recorded compromised growth when AMFs and phosphorus were not used. These plants presented shoot dry biomass yield of $0.054 \mathrm{~g} /$ plant; whereas, plants inoculated with $R$. clarus and $C$. etunicatum recorded shoot dry biomass yield of 1.3 and $0.63 \mathrm{~g} /$ plant respectively (Figure 1A). Thus, inoculation with AMFs can be an alternative for jambu production in soils presenting low $\mathrm{P}$ concentration. It is important highlighting that $R$. clarus was efficient for mycorrhizal dependency when plants were grown under $\mathrm{P}$ doses capable of generating higher shoot dry biomass yield. Hippler \& Moreira (2013) assessed the effects of two AMF species (Glomus rosea and R. clarus) and four $\mathrm{P}$ doses $(0,75,150$ and $225 \mathrm{mg} \mathrm{kg}^{-1}$ ) on Arachis hypogaea and observed that $G$. rosea presented mycorrhizal dependency values between $40 \%$ and $37 \%$ at concentrations from 
Table 1. Effect of AMF inoculation and $\mathrm{P}$ doses on nitrogen content in jambu plants $(A$. oleracea). Campos dos Goytacazes, UENF, 2016.

\begin{tabular}{lcccc}
\hline & \multicolumn{5}{c}{$\mathbf{P}\left(\mathbf{m g ~ k g}^{-1}\right.$ of soil) } \\
\hline AMF & $\mathbf{0}$ & $\mathbf{3 0}$ & $\mathbf{6 0}$ & $\mathbf{9 0}$ \\
\hline without AMF & - & $140.6 \mathrm{a}$ & $125.1 \mathrm{~b}$ & $145.05 \mathrm{a}$ \\
R. clarus & $48.2 \mathrm{a}$ & $127.9 \mathrm{ab}$ & $182.4 \mathrm{a}$ & $111.13 \mathrm{~b}$ \\
C. etunicatum & $26.9 \mathrm{a}$ & $105.7 \mathrm{~b}$ & $106.0 \mathrm{~b}$ & $100.20 \mathrm{~b}$ \\
\hline CV $(\%)$ & \multicolumn{5}{c}{13.4}
\end{tabular}

Values followed by the same letter in the column don't differ significantly (Tukey $\mathrm{p}>0.05$ ); $\mathrm{nd}=$ not detected.

Table 2. Effect of AMF inoculation and $P$ doses total phenol content and spilanthol percentage in jambu plants (A. oleracea). Campos dos Goytacazes, UENF, 2016.

\begin{tabular}{|c|c|c|c|}
\hline$P$ doses $\left(m g \mathrm{~kg}^{-1}\right)$ & AMF & $\begin{array}{l}\text { Total phenol content } \\
\text { (mg/plant) }\end{array}$ & Spilanthol (\%) \\
\hline & without AMF & - & - \\
\hline \multirow[t]{3}{*}{0} & G. clarus & $14.8 \mathrm{a}$ & $2.40 \mathrm{a}$ \\
\hline & C. etunicatum & $8.2 \mathrm{~b}$ & nd \\
\hline & without AMF & $27.3 \mathrm{a}$ & $0.27 \mathrm{~b}$ \\
\hline \multirow[t]{3}{*}{30} & G. clarus & $35.4 \mathrm{a}$ & $2.03 \mathrm{a}$ \\
\hline & C. etunicatum & $35.9 \mathrm{a}$ & $1.09 \mathrm{ab}$ \\
\hline & without AMF & $48.4 \mathrm{~b}$ & $0.76 \mathrm{c}$ \\
\hline \multirow[t]{3}{*}{60} & G. clarus & $64.3 \mathrm{a}$ & $2.68 \mathrm{~b}$ \\
\hline & C. etunicatum & $52.1 \mathrm{~b}$ & $5.20 \mathrm{a}$ \\
\hline & without AMF & $56.9 \mathrm{a}$ & $4.40 \mathrm{a}$ \\
\hline \multirow[t]{2}{*}{90} & G. clarus & $50.3 \mathrm{ab}$ & $3.70 \mathrm{a}$ \\
\hline & C. etunicatum & $46.4 \mathrm{~b}$ & $5.20 \mathrm{a}$ \\
\hline $\mathrm{CV}(\%)$ & & 14.6 & 30.0 \\
\hline
\end{tabular}

Values followed by the same letter in the column don't differ significantly (Tukey $\mathrm{p}>0.05$ ); $\mathrm{nd}=$ not detected.

0 to $75 \mathrm{mg} \mathrm{kg}^{-1}$ of $\mathrm{P}$, respectively. Mycorrhizal dependency value recorded for $R$. clarum reached $27 \%$ without fertilization. This outcome shows that the larger the amount of $\mathrm{P}$ in the soil, the lower the dependency of $R$ clarum.

Plants inoculated with $R$. clarus, without phosphate fertilization, recorded $80.5 \%$ total phenol content increase in comparison to the ones inoculated with C. etunicatum (Table 2). This AMF species also presented increased total phenol content when plants were grown under $\mathrm{P}$ dose of $60 \mathrm{mg} \mathrm{kg}^{-1}$. Besides the benefits to plant nutrition, AMF also contribute to the accumulation of different compounds deriving from secondary metabolism (Carlsen et al., 2008). Jambu plants grown without phosphate fertilization and inoculated with $R$. clarus recorded the highest total phenols content in jambu plants. This AMF species also presented increased phenols contents, even after the addition of $60 \mathrm{mg} \mathrm{kg}^{-1}$ of $\mathrm{P}$ to the soil. It is known that the mycorrhizal colonization of the roots by AMF happens in many stages; however, each of these stages is featured by morphological and physiological changes in the host. These physiological changes are featured by the activation of different metabolic routes, and this process leads to the accumulation of different compounds deriving from secondary metabolism, such as phenolic compounds, mainly flavonoids (Carlsen et al., 2008).

Spilanthol concentration was influenced by AMF inoculation and by the $\mathrm{P}$ doses applied to the soil (Table 2). Its concentration in plants inoculated with $R$. clarus, without phosphate fertilization, was equivalent to $2.4 \%$ of the total rate of substances found in the essential oil. Spilanthol was not detected in plants inoculated with C. etunicatum likely because of the small amount of oil extracted during this treatment. Jambu plants inoculated with $R$. clarus and fertilized with $30 \mathrm{mg} \mathrm{kg}^{-1}$ recorded 7.5 times increase in spilanthol rates in comparison to the non-inoculated ones. However, jambu plants inoculated with C. etunicatum and fertilized with $60 \mathrm{mg}$ $\mathrm{kg}^{-1} \mathrm{P}$ presented increase by 3.4 and 6.7 times higher than that of plants subjected to the treatment without inoculation, respectively, at the same $\mathrm{P}$ dose. Table 2 shows that the spilanthol content did not present statistically significant differences between the assessed AMFs when plants were not fertilized with 90 $\mathrm{mg} \mathrm{kg}^{-1}$ of P. Thus, based on the results, it is possible making some saving with spilanthol production by carrying out phosphorus fertilization though the AMF species $R$. etunicatum, at the dose of $60 \mathrm{mg} \mathrm{kg}^{-1} \mathrm{P}$, since spilanthol concentration at doses 60 and $90 \mathrm{mg} \mathrm{kg}^{-1}$ led to equal spilanthol contents.

Jambu plants have been gaining the attention of the pharmaceutic industry due to the biological activities, most of them attributed to spilanthol. It is a $\mathrm{N}$-alkylamide produced from unsaturated fatty acids that work as amide and from decarboxylation of amino acids isoleucine and valine (Greger, 1984). Based on the present results, inoculation with AMFs increased spilanthol at $\mathrm{P}$ doses up to $60 \mathrm{mg} \mathrm{kg}^{-1}$. Mycorrhizal associations change carbon biochemistry in plants, and it results in many physiological and metabolic changes such as those in the content of amino acids and fatty acids and in secondary metabolites (Whiteside et al., 2012; Wang et al., 2017; Monnerat et al., 2018). Thus, Sarah \& Ibrar (2016) assessed the influence of AMFs and phosphate doses on Helianthus annuus plants and found that their combinations and phosphate doses increased fatty acids production. Whiteside et al. (2012) reported that AMFs increased amino acids concentration in mycorrhizal 
plants. Therefore, AMFs are important to increase spilanthol synthesis in jambu plants, as shown in the current study.

Shoot dry biomass yield in jambu plants and $\mathrm{P}, \mathrm{K}, \mathrm{Ca}$ and $\mathrm{Mg}$ contents get higher when plants are inoculated with the AMF species $R$. clarus at the lowest $\mathrm{P}$ doses. This species also increases the total phenols content in these plants when they are fertilized with $60 \mathrm{mg}$ $\mathrm{kg}^{-1} \mathrm{P}$. This dose increases spilanthol concentration in jambu plants inoculated with AMF species C. etunicatum.

\section{ACKNOWLEDGEMENTS}

The authors are grateful to $\mathrm{PhD}$ Professor Sérgio Antônio Lopes de Gusmão from the Rural Federal University of Amazonia for making available the jambu seeds used in our study. They also thank CAPES and FAPERJ for the financial support.

\section{REFERENCES}

ANDERSON, JM; INGRAM, JSI. 1993. Tropical soil biology and fertility: a handbook of methods. Soil Science 157: 265.

AUGÉ, RM; TOLER, HD; SAXTON, AM. 2016. Mycorrhizal stimulation of leaf gas exchange in relation to root colonization, shoot size, leaf phosphorus and nitrogen: a quantitative analysis of the literature using meta-regression. Frontiers in Plant Science 7: 1084.

BARBOSA, AF; CARVALHO, MG; SMITH, RE; SABBA-SRUR, AUO. 2016. Sphilantol: occurrence, extraction, chemistry and biological activities. Revista Brasileira de Farmacognosia 26: 128- 133

BONFIM, MVP; SILVA, FSB; MAIA, LC. 2015. Production of secondary metabolites by mycorrhizal plants with medicinal or nutritional potential. Acta Physiologiae Plantarum 37: 27

CARLSEN, SCK; UNDERSTRUP, A; FOMSGAARD, IS; MORTENSEN, AG, RAVNSKOV, S. 2008. Flavonoids in roots of white clover: interaction of arbuscular mycorrhizal fungi and a pathogenic fungus. Plant and Soil 302: 33-43.

CHAKRABORTY, A; DEVI, RKB; SANJEBAM, R; KHUMBONG, S; THOKCHOM, IS. 2010. Preliminary studies on local anesthesic and antipyretic activies of Spilanthes acmella Murr. in experimental animals models. Indian Journal of Pharmacology 42: 277-279.

ESCOBEDO-MARTÍNEZ, C; GUZMÁNGUTIÉRREZ, SL; HERNÁNDEZ-MÉNDEZ,
MM; CASSANI, J; TRUJILLO-VALDIVIAA, A; OROZCO-CASTELLANOS, LM; ENRÍQUEZ, RG. 2017. Heliopsis longipes: anti-arthritic activity evaluated in a Freund's adjuvant-induced model in 383 rodents. Revista Brasileira de Farmacognosia 27: 214-219.

FREITAS, MSM; MARTINS, MA; CARVALHO, AC. 2006. Growth and mineral composition of mint in response to arbuscular mycorrhizal fungi inoculation and phosphorus fertilization. Horticultura Brasileira 24: 11-16.

GERBINO, A; SCHENA, G; MILANO, S; MILELlA, L; BARBOSA, AF; ARMENTANO, F; PROCINO, G; SVELTO, M; CARMOSINO, M. 2016. Spilanthol from Acmella oleracea lowers the intracellular levels of cAMP impairing NKCC2 phosphorylation and water channel AQP2 membrane expression in mouse kidney. PLoS One 11 (5).

GERDEMANN, JW; NICOLSON, TH. 1963. Spores of mycorrhizal endogone extracted from soil by wet sieving and decanting. Transactions of the British Mycological Society 84: 679-684.

GIOVANNETTI, M; MOSSE B. 1980. An evaluation of techniques for measuring VA mycorrhizal infection in roots. New Phytologist 84: 489-500.

GOBBO-NETO, L; LOPES, NP. 2007. Plantas medicinais: fatores e influência no conteúdo de metabólitos secundários. Quimica Nova 30: 374-381.

GRACE, C; STRIBLEY, PA. 1991. Safer procedure for routine staining of vesicular arbuscular mycorrhizal fungi. Mycological Research 95: 1160-1162.

GREGER, H. 1984. Alkamides: structural relationships, distribution and biological activity. Planta Medica 50: 366-375.

GUSMÃO, MTA; GUSMÃO, SAL. 2013. Jambu da Amazônia [Acmella oleracea (L.) R.K. Jansen]: características gerais, cultivo convencional, orgânico e hidropônico. Belém, BR: UFRA. $135 \mathrm{p}$.

HEITOR, LC; FREITAS, MSM; BRITO, VN; CARVALHO, AJC; MARTINS, MA. 2016. Growth and yield of marigold flowers in response to mycorrhizal inoculation and phosphorus. Horticultura Brasileira 34: 026-030.

HIPPLER, FWR; MOREIRA, M. 2013. Mycorrhizal dependence of peanut plants on phosphorus levels. Bragantia 72: 184-191.

JACKSON, ML. 1965. Soil chemical analysis. USA: Prentice Hall, 498p.

KARAGIANNIDIS, N; THOMIDIS, T; LAZARI, D; PANOU-FILOTHEOU, E; KARAGIANNIDOU, C. 2011. Effect of three Greek arbuscular mycorrhizal fungi in improving the growth, nutrient concentration, and production of essential oils of orégano and mint plants. Scientia Horticulturae 129: 329-334.

MARSCHNER, P. 2012. Mineral nutrition of higher plants. USA: Academic Press. 651p.
MONNERAT, CS; FREITAS, MSM; VIEIRA, IJC; MARTINS, MM; CARVALHO, AJC; SANTOS, PC; LIMA, TC. 2018. Ajmalicine bioproduction in Catharanthus roseus (L) G. Don inoculated with arbuscular mycorrhiza and fertilized 449 with nitrogen. Revista Brasileira Ciencia do Solo 42: 1-12.

MOREIRA, FMS; SIQUEIRA, JO. 2006. Microbiologia e bioquímica do solo. $2^{\circ} \mathrm{ed}$. Lavras, BR: UFLA. 729p.

NISHA, MC; RAJESHKUMAR, S. 2010. Effect of arbuscular mycorrhizal fungi on growth and nutrition of Wedilia chinensis (Osbeck) Merril. Indian Journal of Science Technology 3: 676-678.

OLIVEIRA，PR; ANHOLETO, LA; RODRIGUES, RAF; BECHARA, GH; CASTRO, KNC; MATHIAS, MIC. 2018. The potential of Acmella oleracea (jambu) extract in the control of semi-engorged Rhipicephalus sanguineus (Latreille, 1806) (Acari: Ixodidae) female ticks. International Journal of Acarology 44: 192-197.

PLENCHETTE, C; FORTIN, JA; FURLAN, V. 1983. Growth responses of several plant species to mycorrhizae in a soil of moderate P-fertility. Plant and Soil 70: 199-209.

RIBEIRO, AC; GUIMARÃES, PTG; ALVAREZ, VVH. 1999. Recomendações para o uso de corretivos e fertilizantes em Minas Gerais- ${ }^{a}$ Aproximação. Viçosa, BR: UFV. 360p.

ROCHA, F; MURAOKA, T; SCARAMUZZAA, WLMP; SCARAMUZZA, J. 2012. Efficiency of forage plant species and effect of mycorrhiza on absorption of less available phosphorus in soil. Uniciências 16: 17-24.

RODRIGUES, DS; CAMARGO, MS; NOMURA, ES; GARCIA, VA; CORREA, JN; VIDAL, TCM. 2014. Influence of the fertilization with nitrogen and phosphorus in the production of jambu (Acmella oleracea (L) R.K. Jansen). Revista Brasileira de Plantas Medicinais 16: 71-76.

ROUPHAEL, Y; FRANKENB, P; SCHNEIDER, C; SCHWARZ, D; GIOVANNETTI, M; AGNOLUCCI, M; PASCALEA, S; BONINI, P; COLLA, G. 2015. Arbuscular mycorrhizal fungi act as biostimulants in horticultural crops. Scientia Horticulturae 196: 91-108.

SARAH, S; IBRAR, M. 2016. Effects of arbuscular mycorrhizal fungi on spores density and root colonization of four hybrids of sunflower (Helianthus annuus L.) at different rock phosphate levels. Sarhad Journal of Agriculture 32: 258-266.

WANG, W; SHI, J; XIE, Q; JIANG, Y; YU, N; WANG, E. 2017. Nutrient exchange and regulation in arbuscular mycorrhizal symbiosis. Molecular Plant 10: 1147-1158.

WHITESIDE, MD; GARCIA, MO; TRESEDER, KK. 2012. Amino acid uptake in arbuscular mycorrhizal plants. PLOS ONE 7(10).

YADAV, K; SINGH, N; AGGARWAL, A. 2012. Arbuscular mycorrhizal technology for the growth enhancement of micropropagated spilanthes Acmella Murr. Plant Protection Science 48: 31-36 